Research Article

\title{
Prevalence and diagnosis of bacterial Vaginosis in tertiary care teaching hospital
}

\author{
Farheen $\mathbf{A}^{1}$ Humera $\mathbf{A}^{2}$ \\ ${ }^{1}$ Dr. Ayesha Farheen, Assistant Professor, Department of Pathology, ESIC Medical College, Gulbarga, ${ }^{2}$ Dr. Aisha \\ Humera, Assistant Professor, Department of Obstetrics and Gynaecology, KBNIMS, Gulbarga, Karnataka, India.
}

Address for Correspondence: Dr. Ayesha Farheen, E-mail id:drayesha_999@yahoo.co.in

\begin{abstract}
Introduction: Bacterial vaginosis is the most common cause of vaginal discharge among women in reproductive age. The normal flora of the vagina varies from person to person, but lactobacilli are usually the preponderant organism. Bacterial flora also contains other aerobic and anaerobic microorganisms. Some of these are considered to be pathogenic. It is recognized that, bacterial vaginosis may be associated with pelvic inflammatory disease, preterm premature rupture of the membranes (PROM), post operative gynaecologic infections and abnormal Papanicolaou smear. Objective: 1) to find the prevalence of bacterial vaginosis. 2). To find the most cost effective reliable method for diagnosis of bacterial vaginosis. Method: A total of 360 consecutive women with complaints of vaginal discharge were considered for the study. The study was undertaken from January 2015 till June 2016 at KBN medical college and hospital, Gulbarga, Karnataka. BV was diagnosed based on Amsel's composite criteria and Nugent's scoring system. pH was determined, Whiff amine test for the presence of fishy odor and the presence of the clue cells on vaginal smear were observed. Gram staining was performed for Nugent's method. Result: Prevalence of BV was $44.16 \%$. Most common affected age group was between 24-35 years. Routinely a combination of various methods are used for the diagnosis of bacterial vaginosis (BV), although nugent criterion is considered as the gold standard method The prevalence rate of BV in present study was high. Conclusion: With limited resources in developing countries, there is a great need for inexpensive diagnostic methods for bacterial vaginosis. Amsel's criteria is as good as Nugent's scoring in diagnosis of BV and it is simple, easy, cost effective, fast and reliable, and can be done in OPD which can be used for precise and fast treatment.
\end{abstract}

Keywords: Bacterial vaginosis, Amsel's criteria, Nugents scoring, Clue cells, Whiff test, Vaginal Discharge

\section{Introduction}

Bacterial vaginosis (BV) is the most common cause of vaginitis in women of reproductive age group [1]. It the most common infection encountered in the Gynaecological outpatient setting. The prevalence of Bacterial vaginosis in adult population ranges from $17.8 \%$ to $63.7 \%$ in India [2]. The normal flora of the vagina varies from person to person, but lactobacilli are usually the preponderant organism. Bacterial flora also contains other aerobic and anaerobic microorganisms. Vaginitis and vaginosis refer to vaginal infection, skin diseases involving the vagina, or a disruption of the normal vaginal flora. BV is a poly-microbial synergistic infection characterized by complex changes in the normal vaginal flora attributed to reduction in the

Manuscript received: $20^{\text {th }}$ July 2017

Reviewed: $30^{\text {th }}$ July 2017

Author Corrected: $7^{\text {th }}$ August 2017

Accepted for Publication: $14^{\text {th }}$ August 2017 prevalence of Lactobacilli and an increase in the concentration of pathogenic organisms [3]. It is recognized that, bacterial vaginosis may be associated with pelvic inflammatory disease, preterm premature rupture of the membranes (PROM), spontaneous abortion, post operative infections [4,5].

All these organisms have a synergistic role in producing the symptoms of BV. The condition is although common especially in low settings but underdiagnosed [6]. Amongst pregnant teenagers in particular, routine screening for the agents of bacterial vaginosis, especially mycoplasma hominis is worthwhile. In fact, routine screening of all pregnant women, by cervicovaginal smears or wet mount, is probably desirable as the general prevalence of bacterial vaginosis in the third trimester is $14 \%$. The presence of anaerobes 
(principally bacteroides species) and increase in the numbers of Escherischia coli, Klebsiella aerogenes, and streptococcus faecalis are associated with septic abortion. Similarly, post caesarean endometritis is associated with a variety of bacterial vaginosis organisms. Of equal concern is the apparent association of bacterial vaginosis micro-organisms with amniotic fluid infection, chorioamnionitis and premature labour [7].

Two most widely accepted methods for the diagnosis of bacterial vaginosis, Amsels composite criteria and nugents grams stain evaluation of bacterial morphotypes are not routinely practiced $[8,9]$.

Although diagnosis by Amsel's composite criteria includes clinical diagnosis and a few simple laboratory tests.

Bacterial vaginosis can also be diagnosed by Spiegel's and Nugent's criteria. Both the criteria's are based on the evaluation of the normal flora in the Gram stained smears of the vaginal discharge [10].

This study aimed to monitor the prevalence of BV among women complaining from vaginitis and excessive vaginal discharge and evaluation of the different commonly used methods of diagnosis.

\section{Material and Methods}

This Study was conducted in the department of pathology of KBNIMS, Gulbarga from January 2015 till June 2016.

A total of 360 consecutive women with symptoms of vaginitis or excessive vaginal discharge were enrolled for this study.

Inclusion criteria: All the patients, clinically having the symptoms of vaginal discharge, were included in the study.

Exclusion criteria: Patients in menstrual period and patients who had taken antibiotics or received any treatment for vaginitis with in the previous month were excluded from this study.

Objective of the study:

1. To find out the prevalence of bacterial vaginosis

2. To find out the most reliable method for diagnosis of bacterial vaginosis.

\section{Methods}

With the prior consent, patient was subjected to detail clinical examination. All patients were examined using speculum without lubrication and the presence of vaginal erythema and vaginal discharge was recorded with description of the color, consistency and odour of discharge. Posterior fornix was swabbed with a cotton tipped applicator.

PH was determined by using pH strips. Whiff's amine test was done as follows the swab was mixed with two drops of 10 percent potassium hydroxide on a glass slide.

This solution was immediately examined for the presence of fishy amine odour. A second sample was obtained with another swab and smears were made, for Gram's Stain, and Papanicolaou Stain. All the smears were carefully examined and data obtained was analyzed.

Clue Cells: Clue cells are epithelial cells to which a large number of bacteria are attached that the entire cell border is obscured and appears serrated. If the clue cells constitute $20 \%$ or more of the epithelial cells in the high power field it is considered positive Clue cells consist of small, club-shaped, dark-blue stained bacteriae accumulated on the surface of large squamous cells indicating the possibility of Gardnerella vaginalis infection $[11,12]$.

Bacterial vaginosis may be diagnosed clinically by Amsel's criteria. Clinical diagnosis using Amsel criteria requires that at least three of the following four criteria are met: 1) a homogenous, adherent vaginal discharge, 2) vaginal $\mathrm{pH} 4.5 \mathrm{or}$ higher, 3) an amine odour to the vaginal discharge, and 4) The presence of clue cells [7].

Nugents scoring system: The vaginal discharge was smeared on a microscopic slide, air dried, heat fixed and stained with gram stained. Each bacterial morpho-type was quantitated under an oil immersion objective (100x) by using the following scheme: $1+,<1$ per field; $2+, 1$ to 4 per field; $3+, 5$ to 30 per field; $4+,>30$ per field. 
Table-1: Nugent scoring of Gram stained smear for bacterial vaginosis

\begin{tabular}{|c|c|c|}
\hline Organism Morpho type & Number/oil immersion field & Score \\
\hline Lactobacillus - like (parallel sided, gram positive rods) & $>30$ & 0 \\
& $5-30$ & 1 \\
& $1-4$ & 3 \\
& $<1$ & 4 \\
\hline Mobiluncus- like (curved, gram negative rods) & 0 & 2 \\
& $>5$ & 0 \\
\hline Gardnerella/bacteroides- like (tiny, gram variable & $<1-4$ & 4 \\
coccobacilli and pleomorphic rods with vacuoles) & 0 & 3 \\
& $>30$ & 2 \\
\hline
\end{tabular}

After the amount of each morphotype detected on the smear was graded it was then allocated a score as shown in Table (1). Then total score calculated from 0 to 10. A score of 1-3, considered normal, a score of 4-6 considered intermediate (means an intermediate state between normal and BV) and a score of 7 to 10 was consistent with BV. This method is considered the gold standard for diagnosis of BV.

\section{Results}

A total of 360 women with complaint of vaginal discharge were examined for the presence of bacterial vaginosis. Salient features observed in this study were as following.

Prevalence: out of 360 patients, diagnosis of bacterial vaginosis was made in $159(44.16 \%)$ patients.

Age : Age of the patients ranged from 19 years to 70 years and the majority of the patients were in the age group of $24-$ 35 years $(44.16 \%)$, indicating that there is a high incidence of BV in young individuals in the reproductive age group. The commonest clinical manifestations associated with bacterial vaginosis were homogenous grey white discharge and foul smelling discharge, followed by itching, low backache and burning micturition.

Table-2: Prevalence of bacterial vagisosis by Amsels criteria:

\begin{tabular}{|c|c|c|c|}
\hline Serial No & Variable & Positive & Percentage \\
\hline 1. & Homogenous discharge & 159 & 100 \\
\hline 2. & $\mathrm{Ph}>4.5$ & 145 & 91.2 \\
\hline 3. & Whiffs amine test & 155 & 97.5 \\
\hline 4. & Clue cells & 135 & 84.9 \\
\hline
\end{tabular}

153(96.2\%) cases were diagnosed as bacterial vaginoses by Amsels criteria

Table-3: Prevalence of bacterial vaginosis by Nugents scoring:

\begin{tabular}{|c|c|c|}
\hline S. No & Score & No of cases \\
\hline 1 & $0-3$ & $120(33.3)$ \\
\hline 2. & $4-6$ & $81(22.5)$ \\
\hline 3. & $7-10$ & $159(44.16 \%)$ \\
\hline Total & Total & $\mathbf{3 6 0}$ \\
\hline
\end{tabular}




\section{Discussion}

Bacterial vaginosis (BV) is an ecological disorder of the vaginal microbiota that affects millions of women annually and is associated with numerous adverse health outcomes including pre-term birth and the acquisition of sexually transmitted infections [12].

In this study, we recorded the prevalence of BV among population and determined and compared the different diagnostic methods of BV with Nugent score as a gold standard to evaluate them.

In our study prevalence of bacterial vaginosis was $44.16 \%$. Similar prevalence rates were found in other studies like $41.5 \%$ by nawani et al [13], $53 \%$ by Tiyyagura et al [14] and $48 \%$ by rao s et al [15].

The highest number of BV positive cases were noted in the age group of 24-35Yrs (44.16\%). This agrees with previous studies, who reported that vaginal infections commonly occur in women of reproductive age i.e between 25-30 years [16]. Changes in structure and composition of vaginal ecosystem maybe influenced by age, infections, methods of birth control by using contraceptives, frequency of sexual activities and number of sexual partners [15].

Whiff's test was first described by Pheifer et al; It is both sensitive and specific. The test result is positive if an ammoniacal odour is released when potassium hydroxide is mixed with the discharge. The release of the odour is transient [17].

Table 4: Clinical manifestations of Bacterial vaginosis in different studies.

\begin{tabular}{|c|c|c|c|c|c|c|c|}
\hline $\begin{array}{l}\text { S. } \\
\text { no }\end{array}$ & 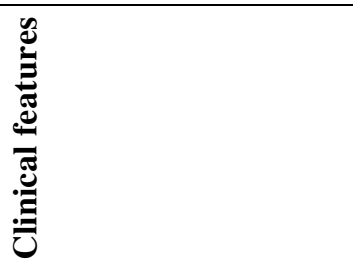 & 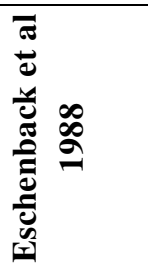 & 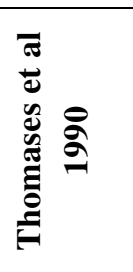 & 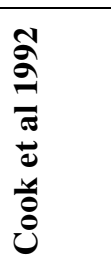 & 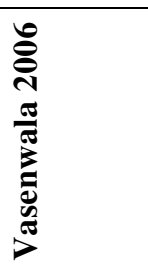 & 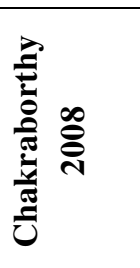 & 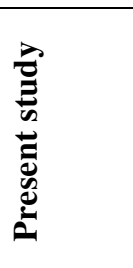 \\
\hline 1 & Homogenous discharge & $69 \%$ & $52 \%$ & $63 \%$ & $78.4 \%$ & $75 \%$ & 63.64 \\
\hline 2 & $\mathrm{PH}>4.5$ & $96.5 \%$ & $92 \%$ & $100 \%$ & $63.6 \%$ & $100 \%$ & $100 \%$ \\
\hline 3 & Positive amine test & $43 \%$ & $84 \%$ & $100 \%$ & $54 \%$ & $55 \%$ & $63.64 \%$ \\
\hline 4 & Clue cells & $78 \%$ & & $94 \%$ & 34.88 & $100 \%$ & $81.88 \%$ \\
\hline
\end{tabular}

Bacterial vaginosis may be diagnosed clinically by Amsel's criteria. Three or more of the following feature are found 1) a homogenous, adherent vaginal discharge, 2) vaginal $\mathrm{pH} 4.5$ or higher, 3) an amine odour to the vaginal discharge, and 4) The presence of clue cells [7].

Clue cells are quite specific in papanicolaou-stained smears, as well as in Gram stained smears, for detecting shift in flora from lactobacillus predominant to the anaerobic, Gardnerella Vaginalis population likely to be associated with bacterial vaginosis [18].

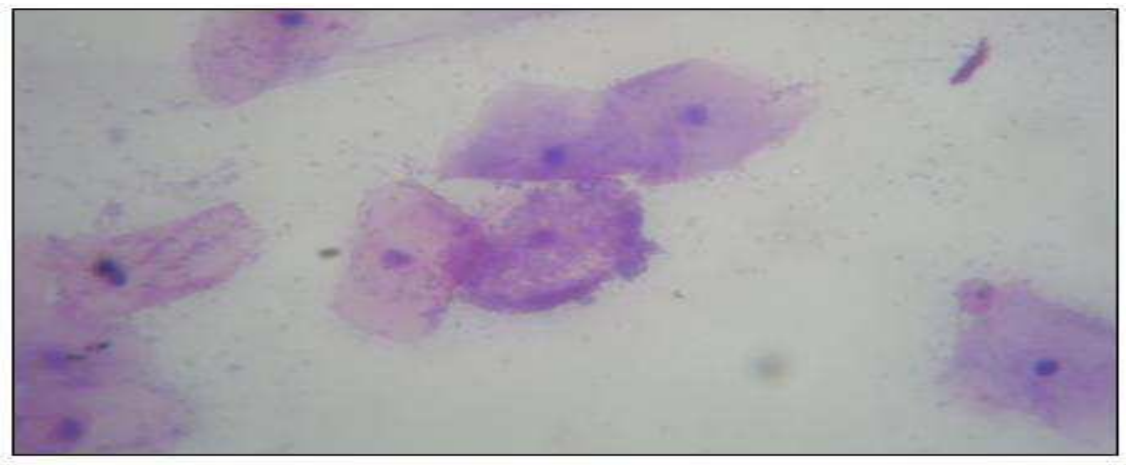

Fig-1: Vaginal smear showing clue cell. (Gram) 


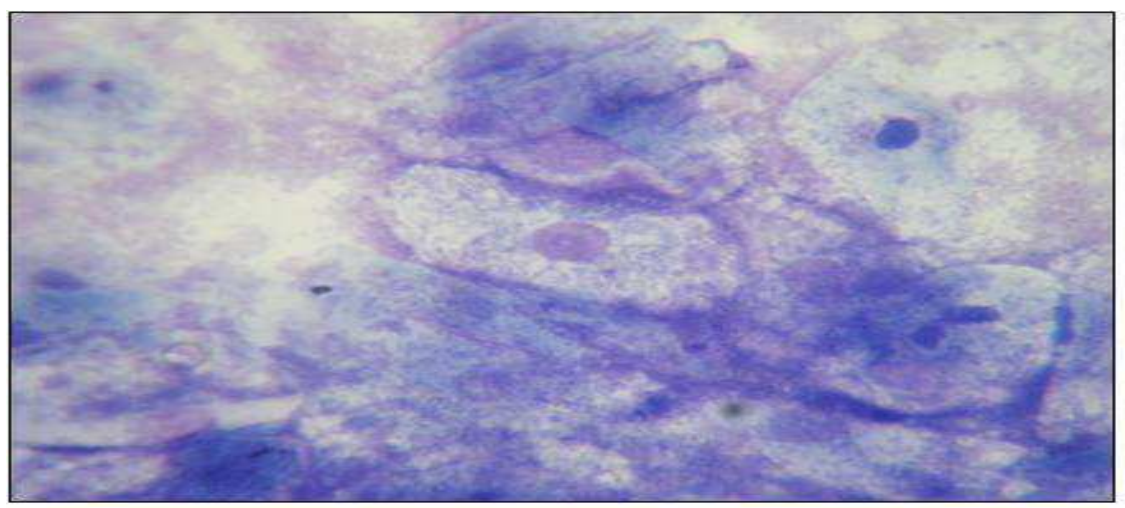

Fig-2: Vaginal smear showing clue cell (Giemsa)

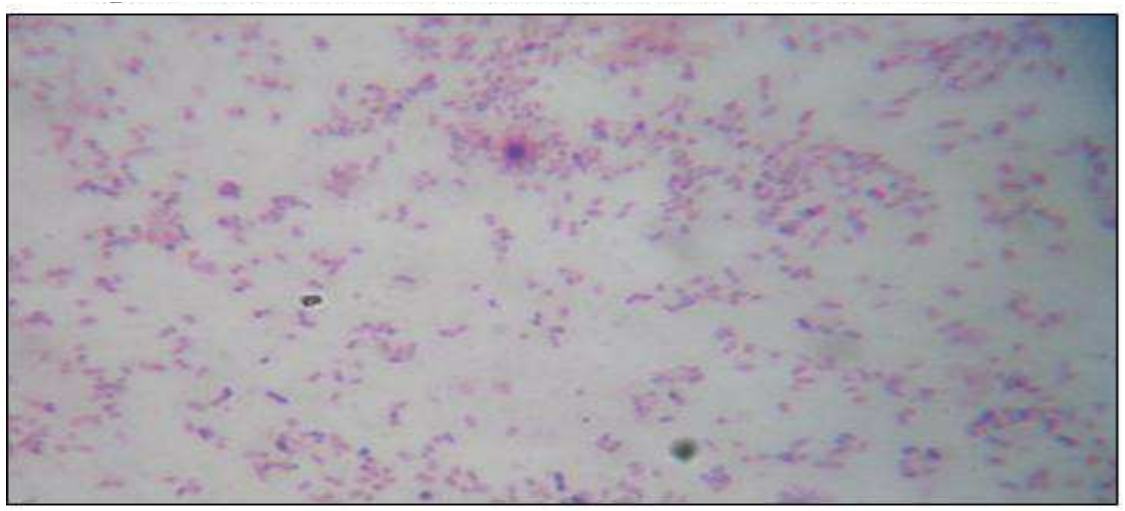

Fig-3: Vaginal smear in bacterial vaginosis showing gram variable coccobacilli and absent lactobacilli (Gram)

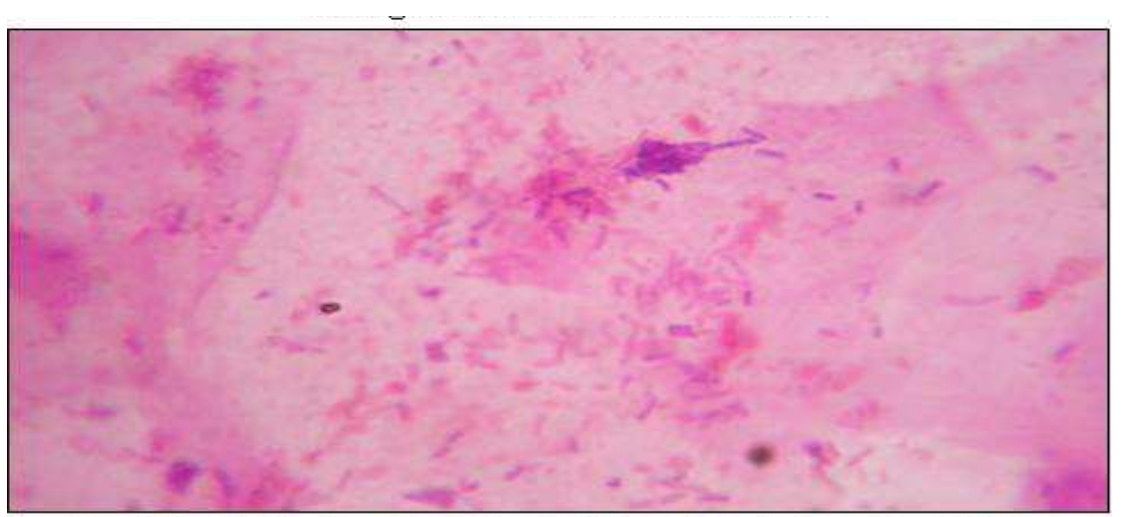

Fig-4: Vaginal smear showing shift in vaginal flora with occasional lactobacilli

Bacterial vaginosis can also be diagnosed by Spiegel's and Nugent's criteria. Both these criteria are based on the evaluation of the normal flora in the Gram stained smears of the vaginal discharge [3]. Gram staining of vaginal discharge is a reliable means of establishing the aetiology of a vaginosis (greater than 40 Gram-negative or Gramvariable coccobacilli per microscopic field at $1000 \mathrm{x}$ magnification under oil immersion), especially when there is an anaerobic vaginosis [8].

Among the 360 patients, 170(47\%) patients were diagnosed with bacterial vaginosis by Amsel Criteria. 173(48\%) patients had vaginal discharge, 170(47\%) had a positive whiff test, 163(45\%) had clue cells and $159(44 \%)$ had ph>4.5, and $173(48 \%)$ were diagnosed by Nugent's Scoring. Hence sensitivity of Amsels criteria was $96.2 \%$. Similar results were reported by Gratco et al [19]. 
Research Article

The Gram stain provides a direct look at the bacteriologic morphologies and is thus unaffected by factors such as menses, recent intercourse, which may alter $\mathrm{pH}$ and by technical variables such as observer interpretation of clue cells. The vaginal gram stain has been shown to have excellent intra and interobserver reproducibility [21]. The main difficulty for the clinician is the lack of access to direct microscopy, hence it is advised that Amsel's criteria may be used for the diagnosis of $\mathrm{BV}$ at the OPD as it is simple, easy, and cost effective and fast and reliable [13].

Nevertheless, some alternative diagnostic methods have been developed, which do not offer a huge advantage over the classical methods. Given these considerations, methods like Amsel and Nugent's scoring remain the most practical, viable and economical options for diagnosing bacterial vaginosis, especially in developing countries [8,22].

Currently, the Nugent scoring method is the most frequently used laboratory-based diagnostic tool for detecting BV, and it is considered as the gold standard although its inter- and intraobserver reliabilities have been questioned [23]. The field size of the microscope has a bearing on the results which is another issue of concern [24].

Nugent's score was more sensitive than Amsel's criteria for diagnosis of BV. But $90 \%$ of women with BV can be diagnosed correctly based on Amsels criteria [25].

As the prevalence of BV in developing countries are high, countries with limited resources have a great need for inexpensive diagnostic methods that are reliable and unifies clinical and microbiological parameters to make it more sensitive while retaining its specificity.

\section{Conclusion}

Prevalence of bacterial vaginosis was $44.6 \%$. Amsel's criteria were comparable with Nugent's criteria for the diagnosis of bacterial vaginosis and it is simple, easy, cost effective, reliable, and can be used for precise and fast treatment.

Funding: Nil, Conflict of interest: None initiated, Permission from IRB: Yes

\section{References}

1. Cherpes TL, Meyn LA, Krohn MA, Lurie JG, Hillier SL. Association between acquisition of herpes simplex virus type 2 in women and bacterial vaginosis. Clin Infect Dis. 2003 Aug 1;37(3):319-25. Epub 2003 Jul 15.

2. International Institute for Population Sciences (IIPS) and ORC Macro. 2000. National Family Health Survey (NFHS-2), Mumbai, India; 1998- 99: 307360.

3. Sobel JD. Bacterial vaginosis. Annu Rev Med. 2000;51:349-56.

4. Hillier SL,krohn MA,Klebanoff SJ,Eschenback DA. The relation ship of hydrogen peroxide producing lactobacilli to bacterial vaginosis and genital microflora in pregnant women .Obstet Gynecol 1992 Mar; 79 (3): 369-73.
5. Henry MR. The Bethesda System 2001: an update of new terminology for gynecologic cytology. Clin Lab Med. 2003 Sep;23(3):585-603.

6. Leitich H, Bodner-Adler B, Brunbauer M, Kaider A, Egarter C, Husslein P. Bacterial vaginosis as a risk factor for preterm delivery: a meta-analysis. Am J Obstet Gynecol. 2003 Jul;189(1):139-47.

7. Amsel R, Totten PA, Spiegel CA, Chen KC, Eschenbach D, Holmes KK. Nonspecific vaginitis. Diagnostic criteria and microbial and epidemiologic associations. Am J Med. 1983 Jan;74(1):14-22.

8. Nugent RP, Krohn MA ,Hillier SL. Reliability of diagnosing bacterila vaginosis is improved by a standardised method of gram stain interpretation. J Clin Microbiol. 1991 Feb;29(2):297-301.

9. Langsford MJ, Dobbs FF, Morrison GM, Dance DA. The effect of introduction of a guideline on the management of vaginal discharge and in particular bacterial vaginosis in primary care. Fam Pract 2001 june; 18(3):253-7

10. Laxmi U, Bhat G, Kotigadde S, Shenoy S. Comparison of the Methods of Diagnosis of Bacterial Vaginosis. Journal of Clinical and Diagnostic Research. 2011 June; 5(3):498-501. 
11. Eschenbach DA, Hillier S, Critchlow C, Stevens C, derouen $\mathrm{T}$, Holmes KK. Diagnosis and clinical manifestations of bacterial vaginosis. Am J Obstet Gynecol. 1988 Apr;158(4):819-28.

12. Yoshimura K, Morotomi N, Fukuda K, et al. Intravaginal microbial flora by the $16 \mathrm{~S}$ rrna gene sequencing. Am J Obstet Gynecol 2011; 205: 235.e1-9.

13. Nawani M, Sujatha R. Diagnosis And Prevalence Of Bacterial Vaginosis In A Teritiary Care Centre At Kanpur. JEMDS 2013 June; 2(22): 3959- 62.

14. Tiyyagura S, Taranikanti M, Ala S, Mathur DR. Bacterial Vaginosis in Indian Women in the Reproductive Age Group. Int J of Biomed Res. 2012; 3 (8) 371-373.

15. Rajeshwar Rao S, Pindi KG, Rani U,Sasikala G,Kawle V. Diagnosis of Bacterial Vaginosis :Amsel's criteria vs Nugent's scoring. Sch. J. App. Med. Sci. 2016 June; 4(6C):2027-2031

16. Thulkar J, Kriplani A, Agarwal N, Vishnubhatla S. Aetiology \& risk factors of recurrent vaginitis \& its association with various contraceptive methods. Indian J Med Res. 2010 Jan;131: 83-87.

17. Blackwell A, Barlow D. Clinical Diagnosis Of Anaerobic Vaginosis(non specific vaginitis)-A practical guide.Br J Vener Dis. 1982 Dec; 58 (6): 387-93.

18. Schnadig VS, Davie KD, Shafer SK, Yandell RB, Islam MZ, Hannigan EV. The cytologist and bacterioses of the Vaginal - ectocervical area clues, commas and confusion. Acta Cytol 1989;33(3):287-97.
19. Grataco AE, Figueras F, Barranco M, Ros R, Andreu AA, Pedro L et al.; Prevalence of bacterial vaginosis and correlation of clinical to Gram stain diagnostic criteria in low risk pregnant women. Eur $\mathbf{J}$ Epidemiol. 1999; 15: 913-6.

20.Brand JM, Galask RP. Trimethylamine: the substance mainly responsible for the fishy odor often associated with bacterial vaginosis. Obstet Gynecol. 1986 Nov; 68(5):682-5.

21. Goyal R, Sharma P, Kour I, Aggarwal N, Talwar V. Diagnosis of Bacterial Vaginosis in Women in Labour, jk sciences. 2005; Jan7(1):1-4

22. Schwebke JR, Hillier SL, Sobel JD, mcgregor JA, Sweet RL. Validity of the vaginal gram stain for the diagnosis of bacterial vaginosis. Obstet Gynecol. 1996 Oct;88(4 Pt 1):573-6.

23. Forsum U, Jakobsson T,Larsso $n$ PG et al. An international study of the interobserver variation between interpretations of vaginal smear criteria of bacterial vaginosis. APMIS. 2002 Nov; 110 (11): 811-18.

24. Larsson PG, Carlsson B, Fåhraeus L, Jakobsson T, and Forsum U. Diagnosis of bacterial vaginosis: need for validation of microscopic image area used for scoring bacterial morphotypes. Sex Transm Infect. 2004 Feb; 80(1): 63-67.

25. Thomason JL, Gelbart SM, Anderson RJ, Walt AK, Osypowski PJ, Broekhuizen FF. Statistical evaluation of diagnostic criteria for bacterial vaginosis. Am J Obstet Gynecol. 1990 Jan;162(1):155-60.

\section{How to cite this article?}

Farheen A Humera A. Prevalence and diagnosis of bacterial Vaginosis in tertiary care teaching hospital. Trop J Path Micro 2017;3(3):276-282.doi: 10.17511/jopm.2017.i3.08. 